DOI: http://doi.org/10.21698/simi.2018.fp43

\title{
DESTRUCTION CAVITATION ACTION ON THE MICROBIAL CELLS SIZES
}

Iryna Z. Koval

Lviv Polytechnic National University, Department of General Chemistry, 12 Bandera street, 79013, Lviv, irynazk@gmail.com, Ukraine.

\begin{abstract}
Cavitation influence has different destruction action on the microbial cells that depends on their size, shape, type of bacteria, etc, i.e. it depends on the morphological features of the cells. The effectiveness of this process also depends on the nature of bubbled gas into reactive cavitation zone. Ar/US has shown the highest effectivity of cells destruction conditions regardless of the size of their cells compared with $\mathrm{He} / \mathrm{US}, \mathrm{O}_{2} / \mathrm{US}$ and $\mathrm{CO}_{2} / \mathrm{US}$. Concerning of gas/US-action on the type of microorganisms it was found that yeast cells were destroyed most rapidly, because their sizes are several times larger than bacterial cells.
\end{abstract}

Keywords: bacteria, cavitation, cells size, destruction, gas bubbling, yeast

\section{Introduction}

Biological pollution of water is caused by bacteria, viruses, fungi and higher organisms (Jyoti \& Pandit 2001, Koval 2016, Voloshko 2008, Zhang et al 2006). It is a problem for environment nowadays and needs progressive technology for water treatment. Water treatment is an important factor in ensuring the ecological integrity of water systems (An \& Park 2017). There are many methods of water treatment, but currently, the modern method of water purification is the use of cavitation. It is well known about destructive action of cavitation on the microorganisms (MO) cells in the water medium (Koval et al 2011, Koval et al 2012, Koval et al 2016, Stamper et al 2008). However, these effects could have different influence on the cells, depending on the variety of bacteria. Microbes are characterized by different cell sizes and forms of the outer shells, which may have an ambiguous effect on the process of their destruction and its duration under cavitation action. Therefore, the purpose of the present research is to investigate cavitation influence on the bacteria and yeasts destruction, depending on the size of their cells.

\section{Materials and Methods}

The objects of investigation for destruction process of microbial cells were the following waters: model waters created based on distilled water with adding some types of MO. Micrococcus luteus, Pseudomonas fluorescens, Bacillus cereus, Sarcina lutea bacteria and Saccharomyces cerevisiae yeasts were used as microbial cells for investigations. Effective rate constants of cells destruction $\left(\mathrm{kd}_{\mathrm{d}}\right)$ were calculated after combined action of cavitation and gas influence. Oxygen $\left(\mathrm{O}_{2}\right)$, carbon dioxide $\left(\mathrm{CO}_{2}\right)$, argon ( $\left.\mathrm{Ar}\right)$ and helium (He) were used as an additional source of bubbles in an aqueous medium. The aqueous medium was aerated during whole process of cavitation action on the cell. Saturation of the treated aqueous medium by 


\section{INTERNATIONAL SYMPOSIUM "THE ENVIRONMENT AND THE INDUSTRY", SIMI 2018, PROCEEDINGS BOOK}

different types of gases created additional cavitational embryos in reactive zone. Hence, simultaneous action of gas and ultrasound (US), namely $\mathrm{Ar} / \mathrm{US}, \mathrm{He} / \mathrm{US}$, $\mathrm{O}_{2} / \mathrm{US}, \mathrm{CO}_{2} / \mathrm{US}$ on the individual bacterial cells were used.

The source of cavitation was US waves with oscillation frequency of $22 \mathrm{kHz}$, power of $91 \mathrm{~W}$ and intensity of $1.65 \mathrm{~W} / \mathrm{cm}^{3}$. US oscillation were transmitted by the magnetostrictive emitter immersed into the volume of investigated water $(\mathrm{V}=75$ $\mathrm{cm}^{3}$ ). Experimental conditions were $\mathrm{T}=298 \pm 1 \mathrm{~K}, \mathrm{P}=0.1 \mathrm{MPa}$, process duration $(\mathrm{t})-$ 2 hours.

A nutrient media for cell growth after cavitation treatment was used: for bacteria meat water $\left(1 \mathrm{dm}^{3}\right)$, peptone $(10 \mathrm{~g})$, agar $(15 \mathrm{~g})$ and for yeast - malty mash $\left(1 \mathrm{dm}^{3}\right)$ containing solids (6-8\%) and agar (2\%). Petri dishes were placed in thermostat at the $37^{\circ} \mathrm{C}$ for $48 \mathrm{~h}$ (for bacterial cells) and $30^{\circ} \mathrm{C}$ for $96 \mathrm{~h}$ (for yeast cells).

\section{Results and Discussion}

The specific cavitation effects on the cells wall as well as intergenetic difference in the structures of cells' wall were explained by the resistance of investigated MO. This fact is consistent with some articles during destruction effect of cavitation on different MO: Gram-negative bacteria (total coliforms, fecal coliforms, Pseudomonas spp.), Gram-positive (Clostridium perfringens and fecal streptococci) (Drakopoulou et al 2009); spores of Aspergillus flavus and fungi of Penicillium digitatum (López-Malo et al 2005); E. coli (Patil et al 2009), Microcystis aeruginosa algae (Zhang et al 2006).

As a result, some morphological features, namely cells sizes of investigated MO were detected and presented in Table 1.

Table 1. Morphological features of investigated microorganisms

\begin{tabular}{c|ccc}
\hline \multirow{2}{*}{$\begin{array}{c}\text { Investigated } \\
\text { microorganisms }\end{array}$} & $\begin{array}{c}\text { Coloration by } \\
\text { Gram }\end{array}$ & $\begin{array}{c}\text { Width, } \\
\text { micrometers }\end{array}$ & $\begin{array}{c}\text { Length, } \\
\text { micrometers }\end{array}$ \\
\cline { 2 - 4 } Bacteria & Gram + & 1.3 & 3.42 \\
\hline $\begin{array}{c}\text { Bacillus } \\
\text { cereus } \\
\text { Micrococcus } \\
\text { luteus } \\
\text { Sarcina } \\
\begin{array}{c}\text { lutea } \\
\text { Pseudomonas } \\
\text { fluorescens }\end{array}\end{array}$ & Gram + & 0.7 & - \\
\hline Yram + & 2.2 & - \\
\hline $\begin{array}{c}\text { Saccharomyces } \\
\text { cerevisiae }\end{array}$ & Gram - & 0.53 & 1 \\
\hline
\end{tabular}

It was observed that the larger size cells were easily damaged by gas/US treatment, i.e. the cell stability in cavitation conditions was reversely proportional to the cell size. The value of $k_{d}$ is in the range of $(4.52 \div 7.94) 10^{-4} \mathrm{~s}^{-1}$ for Saccharomyces cerevisiae yeast unlike the value of $\mathrm{k}_{\mathrm{d}}$ in the range of $(2.0 \div 5.0) 10^{-4} \mathrm{~s}^{-1}$ for investigated bacteria types (Table 2), cells size of which is approximately in 10 times smaller from yeast cells size (Table 1). 


\section{INTERNATIONAL SYMPOSIUM "THE ENVIRONMENT AND THE INDUSTRY", SIMI 2018, PROCEEDINGS BOOK}

It could be created dependencies of effective rate constants of MO destruction on their cells size under conditions: $\mathrm{Ar} / \mathrm{US}, \mathrm{He} / \mathrm{US}, \mathrm{O}_{2} / \mathrm{US}, \mathrm{CO}_{2} / \mathrm{US}$ (Table 2). $\mathrm{k}_{\mathrm{d}}$ values as a function of MO size, where the increase of kd values was observed for larger cells. This pattern was observed for all investigated gases, especially for argon. Hence, MO destruction under cavitation action depends on the nature of gas bubbling during whole process. The analysis of nature of gas influence on cells destruction under cavitation conditions showed that these processes occur most effectively in the atmosphere of argon in the reaction medium, independently on genetic origins of the studied MO, their morphological features, initial quantity of cells in the unit volume of water system and size of their cells.

Hence, the relative series of effective MO destruction during gas/US treatment was described below:

$$
k_{d}(\mathrm{Ar} / \mathrm{US})>k_{d}\left(\mathrm{O}_{2} / \mathrm{US} ; \mathrm{He} / \mathrm{US} ; \mathrm{CO}_{2} / \mathrm{US}\right)
$$

The highest effectivity of cells destruction was observed under Ar/US conditions regardless of the cells sizes. The values of effective rate constants of cells destruction under gas/US-action are presented in Table 2.

Table 2. The values of effective rate constants of cells destruction under gas/US conditions

\begin{tabular}{c|cccc}
\hline \multirow{2}{*}{ Microorganisms } & \multicolumn{4}{|c}{$\mathrm{k}_{\mathrm{d}} 10^{4}, \mathrm{~s}^{-1}$} \\
\cline { 2 - 5 } & $\mathrm{Ar} / \mathrm{US}$ & $\mathrm{He} / \mathrm{US}$ & $\mathrm{CO}_{2} / \mathrm{US}$ & $\mathrm{O}_{2} / \mathrm{US}$ \\
\hline Bacteria & & & & - \\
\hline Micrococcus luteus & $3.29 \pm 0.03$ & $1.70 \pm 0.04$ & - & $1.63 \pm 0.05$ \\
Pseudomonas & $3.96 \pm 0.02$ & $0.91 \pm 0.20$ & $2.10 \pm 0.15$ & $3.11 \pm 0.06$ \\
fluorescens & $5.02 \pm 0.03$ & $2.89 \pm 0.04$ & $2.51 \pm 0.04$ & - \\
Bacillus cereus & $5.95 \pm 0.07$ & $3.30 \pm 0.09$ & - & $4.52 \pm 0.01$ \\
Sarcina lutea & & & & \\
\hline Yeast & $7.94 \pm 0.09$ & $5.73 \pm 0.08$ & $5.36 \pm 0.03$ & \\
\hline Saccharomyces &
\end{tabular}

Experimental results were shown almost complete water refinement from yeast for a shorter process time comparing with bacteria (yeast cell size is almost 10 times larger) (Table 1). Thus, among spherical shapes of MO, the most effective destruction was observed for Sarcina lutea, comparing with Micrococcus luteus (the size differs approximately 3.5 times) (Table 1). Similar behavior is observed for rodshaped bacteria: Bacillus cereus and Pseudomonas fluorescens.

\section{Conclusions}

The values of effective rate constants of cells destruction were compared, depending on the gas nature bubbling under cavitation conditions, and it was found that the efficiency of cell destruction under Ar/US is approximatelly two times larger unlike $\mathrm{O}_{2} / \mathrm{US}$, He/US and $\mathrm{CO}_{2} / \mathrm{US}$, regardless of cell size. It was discovered the dependence of the values of effective rate constants of investigated MO destruction of size of their cells that for all studied gases under cavitation conditions was shown growth of $k_{d}$ with an increase of cell size. It was found that yeast cells were 


\section{INTERNATIONAL SYMPOSIUM "THE ENVIRONMENT AND THE INDUSTRY", SIMI 2018, PROCEEDINGS BOOK}

destroyed aproximatelly two times faster than bacterial cells, that could be explained by larger sizes of yeast cells.

\section{References}

An, B-Ch \& Park, E-Y 2017, 'Water Treatment Measures to Improve Ecological Value in Traditional Korean Villages: The Case of Oeam Village, Asan City, Korea', Sustainability, no 9, pp. 1145-1159.

Drakopoulou, S, Terzakis, S, Fountoulakis, M.S, Mantzavinos, D, Manios, T 2009, 'Ultrasound-induced inactivation of gram-negative and gram-positive bacteria in secondary treated municipal wastewater', Ultrasonics Sonochemistry, vol. 16, no.5, pp. 629-634.

Jyoti, KK \& Pandit, AB 2001, 'Water disinfection by acoustic and hydrodynamic cavitation', Biochemical Engineering Journal, no 7, pp. 201-212.

Koval, IZ 2016, 'Cavitational influence on the Bacillus cereus bacteria and Oscillatoria brevis cyanobacteria', $19^{\text {th }}$ International Symposium "The Environment and The Industry”, SIMI 2016, National Research and Development institute for Industrial Ecology ECOIND, Bucharest, Romania, pp. 89-95.

Koval, IZ, Shevchuk, LI \& Starchevskyy, VL 2011, 'Ultrasonic intensification of the natural water and sewage disinfection', Chemical Engineering Transactions, vol. 24, no 3, pp. 1315-1320.

Koval, I, Shevchuk, L, Strogan, O 2012, 'Equipment for magnetic-cavity water disinfection', Chemistry \& Chemical Technology, vol. 2, no. 6, pp. 219-223.

Koval, I, Shevchuk, L \& Starchevskyy, V 2016, 'Short-term cavitational treatment of contaminated water', $15^{\text {th }}$ Meeting of the European Society of Sonochemistry (June 27- July 01), Istanbul, Turkey, pp. 75.

López-Malo, A, Palou, E, Jiménez-Fernández, M, Jiménez-Fernández, SM, Guerrero, S 2005, 'Multifactorial fungal inactivation combining hermosonication and antimicrobials', Journal of Food Engineering, vol. 67, no 1-2, pp. 87-93.

Patil, S, Bourke, P, Cullen, B, Frias, JM, Cullen, PJ, 2009, 'The effects of acid adaptation on Escherichia coli inactivation using power ultrasound', Innovative Food Science and Emerging Technologies, vol. 10, no 4, pp. 486-490.

Stamper, DM, Holm, ER \& Brizzolara, RA 2008, 'Exposure times and energy densities for ultrasonic disinfection of E. coli, Ps. aeruginosa, E. avium, and sewage', Journal of Environmental Engineering and Science, vol. 7, no. 2, pp. 139-146.

Voloshko, L 2008, 'Toxins and other bioactive compounds produced by cyanobacteria in Lake Ladoga', Estonian Journal of Ecology, vol. 57, no 2, pp. 100-110.

Zhang, G, Zhang, P, Wang, B \& Liu, H 2006, 'Ultrasonic frequency effects on the removal of M. aeruginosa', Ultrasonics Sonochemistry, vol. 13, no.5, pp. 446450 . 